\title{
Young refugees in education: the particular challenges of school systems in Europe
}

\author{
Claudia Koehler ${ }^{1}$ and Jens Schneider ${ }^{2^{*}}$ (i)
}

\author{
* Correspondence: \\ jens.schneider@uni-osnabrueck.de \\ ${ }^{2}$ Institute for Migration Research \\ and Intercultural Studies (IMIS), \\ University of Osnabrück, Osnabrück, \\ Germany \\ Full list of author information is \\ available at the end of the article
}

\begin{abstract}
The article confronts comparative research outcomes on factors that helped or hindered the educational success of immigrant youth and second generation in the past decades in several European countries with the institutional responses of European educational systems to the challenges of integrating a substantial number of refugee and other newly arrived children since 2014. Especially studies on the second generation - mostly the offspring of labour migrants - have revealed substantial differences in the long-term effects of specific institutional arrangements in the different systems that can - and should - serve as lessons for the potentially detrimental effects of the ways schools and school systems have reacted to the new influx of immigrant children. In the light of the lessons that could be learned from previous experiences with immigrant children and children of immigrants the article analyses in which way the current responses of different European educational systems to the presence of refugee and other immigrant children reflect these lessons, but also do justice to the particular challenges and specific situations of refugee youth that generally place them at an even higher disadvantage than other migrants. On the other hand, some of the ad-hoc measures for refugee pupils may have the potential of becoming permanent features of the respective educational systems.
\end{abstract}

Keywords: Refugees, Migrant children, Educational systems, Educational policies, Europe

Introduction to the context: refugees in educational systems of EU countries The recent drastic rise in numbers of refugees and asylum applicants between 2014 and 2016 has placed increased pressure on European Union (EU)-Member States to develop strategies for effectively integrating these new arrivals into society. This includes rather short-term provisions, such as housing, language courses and food, but poses also questions about mid- and long-term perspectives of social and structural participation. Considering the high share of children, adolescents and young adults among refugees and asylum applicants, education is one of the most important fields of structural integration, because (a) children and adolescents have a universal human right of access to education, (b) adequate education is a key for socio-economic success and for overcoming disadvantages in European societies, and (c) young asylum seekers and refugees have particular social and emotional needs that quality education can help them overcome (Fazel, Reed, Panter-Brick, \& Stein, 2012). Good quality education fosters social inclusion, economic growth and innovation. While the education

(c) The Author(s). 2019 Open Access This article is distributed under the terms of the Creative Commons Attribution 4.0 International License (http://creativecommons.org/licenses/by/4.0/), which permits unrestricted use, distribution, and reproduction in any medium, provided you give appropriate credit to the original author(s) and the source, provide a link to the Creative Commons license, and indicate if changes were made. 
of migrants may have higher costs than for non-migrants in a short-term perspective, it is a social investment in the long term (Bonin, 2017). This is true from the perspective of receiving societies of the $\mathrm{EU}$, but also from the perspective of building peace and stability in the countries of origin of refugees. Considering that some refugees will eventually return to their countries of origin, the education and skills they acquire in EU countries are tools they can apply for transformation processes in the concerned countries.

Most EU-countries have been facing challenges in providing decent opportunities for integrating newly arriving refugees and immigrants into mainstream education since several decades. But these challenges have intensified since 2015 with the arrival of larger numbers of refugees and asylum seekers (Koehler et al., 2018), forcing systems to adopt large-scale ad-hoc measures and concepts for the educational integration of refugee children - according to their specific financial and structural possibilities, institutional logics and previous experiences.

Since this increased challenge is still relatively recent, there are no longitudinal studies available, let alone comparisons across several countries that would be based on thorough research designs. What we can find are national reports and meta-analyses of these reports that give some first and rather general insights into the educational provisions for newly arrived children in different EU member states. On the other hand, there is quite an extensive body of research and literature on the educational outcomes of migrant and refugee children from previous waves of immigration, including internationally comparative studies on the educational pathways and outcomes, covering mainly the 1970 s to the 2000s. Although migration in the 1960 s to 1980 s, including labour migration and family unification, never peaked in a similar way as did the refugee movement in 2015-16, the challenges posed to the receiving educational systems were high too, especially considering the lack of experiences with anything similar before. The question is whether and to which degree the current responses of the educational systems reflect lessons learned from previous experiences of integrating comparatively large numbers of children from mostly non-native speaking immigrant families.

Considering the situation and political developments in the main origin countries of refugees in Europe, i.e. Syria, Afghanistan, Eritrea and Iraq, children from these groups are not unlikely to stay for many more years - and become immigrant children or, in the case of small children, even second generation. ${ }^{1}$ This should direct our attention (a) to the potential long-term effects of the series of ad-hoc measures that countries implemented in reaction to the influx of high numbers of refugee children; and (b) to the knowledge that has developed, particularly in Northern and Western European countries, during half a century of integrating children from previous waves of immigration into education. What can be learned specifically from internationally comparative studies about what makes "immigrant students succeed" (OECD, 2006, 2015)? Of course, the experiences of the second generation in these studies can date back up to almost three decades, and systems continue evolving in such a considerable lapse of time. At the same time, the situation of refugees differs in some important aspects from those of immigrants: refugees are involuntary migrants, they often experienced trauma and times without schooling, and they are subject to legal restrictions that can also impact their access to education. However, the lessons from the experiences of the second generation can be valid for the contemporary situation, especially with regard to the challenges posed to the educational systems. This will be shown below. 
Drawing on results from the significant body of literature on migrant and second-generation educational trajectories, the article discusses the likelihood of certain mid- and long-term effects of the responses of different European countries to the current challenges of the educational integration of refugee youth.

\section{Studies on previous second generations: what made a difference?}

There is an extensive body of literature on the educational outcomes of children of immigrants since the 1980s. But only since about 20 years the second generation, i.e. the children of immigrants born in the country of immigration, has moved into the focus of migration researchers and educational scientists. Second generation students became of special interest, because they follow their education in the same systems as their peers from non-immigrant families from the very beginning and that means that the degree to which their outcomes and trajectories differ from the latter is a relevant indicator for a system's ability to deal with the specific challenges posed by newly arrived children and those born into immigrant families in the host country.

Only since about less than two decades there are sufficiently high numbers of completed educational careers in the second generation - including higher education and transitions to the labour market - to study full trajectories and their longer-term developments across countries. There have been carried out several large-scale surveys on the second generation offspring from families of diverse immigrant origins in different countries: it started in the U.S. in the early 2000s with the ISGMNY Survey in New York, ${ }^{2}$ the IIMMLA Survey in Los Angeles, ${ }^{3}$ and the CILS Survey in Florida and San Diego, California. ${ }^{4}$ The closest follow-up on these studies in Europe - by content and time - was the TIES Survey that had its data-collection in 2007/8. ${ }^{5}$ But differently from the US studies and also some more recent European surveys, ${ }^{6}$ data for the TIES Survey was collected simultaneously and with the same questionnaire in eight countries: Austria, Belgium, France, Germany, the Netherlands, Spain, Sweden and Switzerland. The TIES-Survey was also the first one which tried to avoid a very frequent comparability problem in international studies that results from setting the focus on the respective main origin groups per country; instead it looked at the same three groups, but compared them across national and local contexts.

What makes these comparative data so relevant also for the current debates on refugee education are the huge differences across countries especially in educational outcomes for the same groups with very similar starting positions - which is a strong indicator that differences in the educational systems and institutional arrangements play an important role (Crul \& Schneider, 2012; Crul et al., 2012). Thus, what effects can be expected from the different institutional responses in countries, regions and cities to, firstly, the immediate challenge of having to provide at least some education for refugee children and newly arrived migrant students, and secondly, the need to create more permanent mid- and long-term structures and means for efficiently integrating newly arrived children and an upcoming new second generation from refugee families into mainstream education? Actually, especially the TIES data allowed assessing both: the influence of family background characteristics and of institutional arrangements on different phases and transition points in second generation educational trajectories.

Three countries looked at by the TIES Survey - Sweden, Germany and the Netherlands - figure among the most prominent receiving countries today, but they 
also represent almost prototypical contrasting cases in comparing the systemic responses to earlier second generations. In this regard, the German educational system in the past can be classified as a de facto-failure in providing immigrant children at least remotely similar chances for educational success compared to the children of native-born parents. While the Swedish system turned out to be a sort of 'opposite' to the German one in almost any regard, the Dutch case is interesting because of its intermediate position, or better: as a system combining elements of both other systems. This can be 'emblematically' illustrated by the relationship between early school leaving at the lower end of performance and the access to higher education at the top end.

In the TIES-comparison, early school leaving ${ }^{8}$ was highest in Germany (together with Austria and Belgium): one third of all Turkish second-generation offspring from low-educated families as compared to only $9 \%$ in Sweden. Here the Dutch results are also not very positive: more than $25 \%$. At the top end, i.e. the percentage of native-born children of low-educated Turkish immigrants who got access to higher education, the results of Germany and Sweden are reversed: 5\% in Germany (by far the lowest of all countries in the comparison) and almost 30\% in Sweden. But in this regard, the results in the Netherlands with $27 \%$ came out much closer to Sweden than to Germany, thus in sum showing a remarkably polarised picture. ${ }^{9}$

The diametrically opposed results in Sweden and Germany correspond to opposed idiosyncrasies in the two educational systems: the ideal in Sweden is to offer (a) all children the best education according to their talents and intellectual capacities, and (b) to do this as independently as possible from children's family or social background - and this included working-class and immigrant children in the past and includes newly arrived young refugees today. The basic underlying logic of the German school system, notwithstanding its internal diversity across regions, has been the reproduction of social class: far before immigration was an issue, workers' children were supposed to learn the basic skills to succeed in apprenticeships or similar and then become workers again - which is reflected especially in the early tracking at age 10 into three quite rigid streams of secondary education. ${ }^{10}$ As studies have repeatedly shown, social class continues to be the single most important determinant for school careers - stronger than migration background. Since by far most of the labour-migrant parents had a working-class background, most immigrant children were almost automatically sorted into the lowest qualifying vocational track and, in general, had to fight hard when the ambitions were higher than that. ${ }^{11}$

On the other hand, the German dual system of vocational training, i.e. divided into half-time vocational schools and half-time practice in companies or workshops, turned out to be quite effective in facilitating young people's transition from school to work, even for those with low diplomas. In difference to the more widespread internship-systems in the Netherlands and Sweden, a successfully completed apprenticeship in Germany is considered a full-fledged working experience and almost a guarantee for finding a stable job afterwards.

The school system in the Netherlands is founded in a similar logic as the German one, also sorting the children into three major tracks with a similar orientation (cf. Crul \& Schneider, 2009). But differently from the latter, the Dutch response to the increasing need for more differentiated pathways and better possibilities also for children from workers' and farmers' families was to create more variations to these tracks, but also to facilitate more permeability between them. ${ }^{12}$ The polarised outcomes shown above can 
be explained with the, in practice, rather thin line between, on the one side, profiting from the permeability between tracks and the possibility of step-by-step moving up the educational ladder, and, on the other side, dropping off that 'long route' after finishing the lowest qualifying track (cf. Crul, 2013). Thus, while not following the Swedish example of emphasising the universal right and value of education to every child, the Dutch system introduced 'repair mechanisms' that have been working considerably well for quite a number of immigrant children, but still made many others fail. The Dutch case is a particularly well-suited illustration for the observation that inhibiting structures affect children of immigrants stronger than their peers of native-born parentage, while they also profit more than the latter from effective support mechanisms.

In cross-country comparison, the analysis of the TIES-data on educational pathways identified the following factors as the most influential in promoting or hampering educational success in the second generation ${ }^{13}$ :

$\checkmark$ Bringing immigrant and working-class children as early as possible into an educational environment, such as early childcare and kindergarten: these children are highly likely to not need extensive second language teaching and support in later stages of their educational pathways, and it offers a low-threshold possibility for also making immigrant parents familiar with the educational system. This is obviously helped when early childhood education is free of costs for the families and when the institutions have well-developed multilingual and intercultural competences.

$\checkmark$ School segregation of whatever kind tends to have a significant negative effect. Because especially the first age cohorts of 'guest worker'-children were believed to go back to their countries of origin at some moment, some countries thought it wise to install parallel systems of mostly practice- and vocation-oriented education for these children, including offering a good part of the teaching in their mother tongue. These children later - especially when it became clear that they were not going back - started with a serious disadvantage into their professional life, and many of them also maintained language-problems well into adulthood.

$\checkmark$ Late or no tracking: the more comprehensive a system, the more likely are immigrant children and children of immigrants able to show their talents and compensate for their relatively disadvantaged starting position from non-academic family backgrounds and as non-native speakers. Early tracking and a lack of permeability between tracks lead to a lot of 'detours' or even aborted careers also for those talented enough to follow the direct academic route. These 'detours' also represent 'moments of risk' and thus also contribute to increasing the risks of early school leaving.

$\checkmark$ On the contrary, second or third chances for so-called 'late bloomers', including, for example, vocational trajectories that allow a way back into general or even higher education, lower the risks of early school leaving and 'fragmented' labour market careers at later stages. Depending on their age at starting 'to bloom', there should also be additional chances for those beyond the age of compulsory education (which, by the way, differs considerably across countries too).

$\checkmark$ Longer educational careers do not only disproportionally improve the chances for higher education, better skilled jobs, lower unemployment rates and above-average incomes, they also have strong positive effects on social aspects, such as the general 
identification with local and national societies, more open attitudes towards the members of other ethnic or religious groups, and resilience against nationalist and fundamentalist convictions.

$\checkmark$ Vocational education and training (VET) can be an effective tool to facilitate a low-threshold and effective access to stable and reasonably well-paid jobs in the first labour market. This works particularly well in systems in which vocational education includes company-based real work-life training. Vocational training is also a good way to promote lifelong-learning processes, such as e.g. alternating phases of education and work also beyond adolescence or as an in-between phase before entering higher education.

$\checkmark$ Paying attention to the parents and engaging in parent-mobilizing activities improves the communication and mutual understanding between schools and families, but also between parents and their children on school matters and tasks which can have positive effects on school outcomes too. At the same time, educational careers should be made as independent as possible from family backgrounds and the parents' actual possibilities or willingness to become actively engaged in supporting their children's school performance.

$\checkmark$ Perceived discrimination is a strong negative predictor for becoming disengaged with one's school career, but also with the society at-large. Moreover, experiences of discrimination usually affect more than the immediate target person, because they are directly or indirectly witnessed by others.

The following section will look at the range of ad-hoc and more structural measures that European countries implemented in order to respond to the challenge of the rapidly and strongly increasing number of children from refugee families between 2014 and 2016. Assuming that a large share of the refugee children who have arrived in the past 5 years are unlikely to return to their countries of origin within short, we see many similarities to the situation in the 1970 and 80s in those European countries which had large-scale labour and refugee migration in those years and whose educational systems had not been well-prepared for rapidly increasing numbers of non-native speaking immigrant children in the classrooms. At the same time, these countries have had the chance to learn lessons from these previous experiences, and this is likely to have had an impact also on the ways in which educational systems and policies responded to the more recent challenges.

\section{Assessing the educational chances of refugee children today}

It is certainly not surprising that the challenge of organising the access to education for the large number of refugee youth at different age levels was mostly responded to within the existing logic and idiosyncrasy of the respective system. So far, it did not lead to major reforms or re-conceptualisations of how to integrate these newly arriving minors into education. The following part of the article tries to bring together what is currently known about the ways in which the different European educational systems have reacted to the challenge and what this meant and means, in practice, for newly arriving children, especially children from refugee families or unaccompanied minors. Because of the above-mentioned lack of comparative empirical findings, ${ }^{14}$ this assessment is based on two major types of sources: (a) a comparative study coordinated and executed by the 
authors in collaboration with partners from universities and practitioners' organisations in seven EU member states, and (b) a critical reading of several reports, such as Dervin, Simpson, and Matikainen (2017); Eurocities (2017); Fundamental Rights Agency (2017) and Grigt (2017).

The comparative study 'Multi-country Partnership to Enhance the Education of Refugee and Asylum-seeking Youth in Europe' (PERAE) made use of existing connections within the SIRIUS-Network (Policy Network on Migrant Education) and included interviews and focus groups with refugee students, teachers, principals, social workers, non-governmental organisations (NGO's), policy makers and other stakeholders involved in the education of refugee youth in 2016 and 2017. The findings were compiled in national reports ${ }^{15}$ and a comparative report (Koehler et al., 2018). The generated data from the comparative study also provided the basis for a SIRIUS Network Policy Brief (Crul, 2017 - see also the article by Crul et al., 2019 in this special issue and Crul, Lelie, Keskiner, Schneider, \& Biner, 2019) and a NESET policy paper by co-author Claudia Koehler (Koehler, 2017). The following part of this article represents a summarising version of this policy paper because there is hardly any other literature that would offer better insights into the state of knowledge and available findings.

This part analyses responses and mechanisms in different European countries with regard to the following main issues: access to education, information about school options for parents and children and the value of prior education, transitions from reception to mainstream classes, and trajectories after compulsory education. The analysis defines challenges that refugees share with migrants, but also identifies those that are unique for refugees and represent additional barriers. The comparison of these issues across countries is summarised in Table 1 at the end of this part.

\section{Access to education}

Access to education is the fundamental precondition for educational success; as such it is usually guaranteed for second-generation, but comes with conditions for refugees. In line with the TIES study's findings, bringing immigrant pupils as early as possible into an educational environment promotes their educational success. While 'early' refers to 'in early years' for migrant pupils who are already in the country, it can be interpreted as 'soon after arrival' for refugee children.

Article 14 of the Directive 2013/33/EU of the European Parliament and Council recognises the importance of time and makes respective provisions: Section 2 provides that access to the education system shall not be postponed for more than 3 months from the date on which the application for international protection was lodged and that preparatory classes, including language classes, shall be provided to minors where it is necessary to facilitate their access to and participation in education. However, because of multiple relocations, difficulties in finding a school place, and administrative procedures, it may take up to 6 months or even longer for children to enter a stable school setting (Eurocities, 2017). Only some countries have regulations that mandate a shorter waiting period - like in Sweden where this has to be provided within 1 month upon arrival (Rydin, Eklund, Högdin, \& Sjörberg, 2012).

Section 1 of the same EU-Directive moreover provides that children of asylum seekers and unaccompanied minors should be granted access to the education system 'under similar conditions as nationals of the host Member State'. An interesting 
Table 1 Overview of systemic differences in the education of refugees in selected EU countries

\begin{tabular}{|c|c|c|c|c|}
\hline \multicolumn{5}{|l|}{ Reception education } \\
\hline $\begin{array}{l}\text { Model of reception } \\
\text { education }\end{array}$ & \multicolumn{3}{|l|}{ Reception classes exist } & $\begin{array}{l}\text { No reception classes/ } \\
\text { refugees enrol directly } \\
\text { in mainstream classes }\end{array}$ \\
\hline \multirow[t]{3}{*}{ Country } & \multicolumn{3}{|l|}{$\begin{array}{l}\text { Austria, Belgium (Flanders), } \\
\text { Germany, Finland, France, } \\
\text { Italy, Sweden, Denmark, } \\
\text { Greece, Hungary, } \\
\text { The Netherlands, Poland }\end{array}$} & $\begin{array}{l}\text { Bulgaria, Slovakia, Spain, UK, } \\
\text { Greece (since school year } \\
\text { 2017/18) }\end{array}$ \\
\hline & $\begin{array}{l}\text { Reception classes as } \\
\text { separate classes }\end{array}$ & \multicolumn{2}{|c|}{$\begin{array}{l}\text { Option to enrol directly } \\
\text { in mainstream classes }\end{array}$} & \\
\hline & $\begin{array}{l}\text { Belgium (Flanders), Denmark, } \\
\text { Hungary, Finland, France, } \\
\text { Germany, The Netherlands, } \\
\text { Greece (in 2016) }\end{array}$ & \multicolumn{2}{|c|}{$\begin{array}{l}\text { Austria, Italy, (parts of) } \\
\text { Germany, Greece, Sweden, } \\
\text { Poland }\end{array}$} & \\
\hline \multicolumn{5}{|l|}{ Tracking } \\
\hline Model of tracking & $\begin{array}{l}\text { First ability tracking } \\
\text { with } 10 \text { years }\end{array}$ & $\begin{array}{l}\text { First ability } \\
\text { tracking with } \\
12 \text { years }\end{array}$ & $\begin{array}{l}\text { First ability } \\
\text { tracking } \\
\text { with } 15 / 16 \\
\text { years }\end{array}$ & No tracking \\
\hline Country & $\begin{array}{l}\text { Germany (but regional } \\
\text { differences) }\end{array}$ & $\begin{array}{l}\text { The } \\
\text { Netherlands, } \\
\text { Greece, } \\
\text { Belgium } \\
\text { (Flanders) }\end{array}$ & $\begin{array}{l}\text { Sweden, } \\
\text { Finland }\end{array}$ & UK \\
\hline \multicolumn{5}{|c|}{ Additional support for refugees and asylum seekers in mainstream schools } \\
\hline $\begin{array}{l}\text { Model of additional } \\
\text { support }\end{array}$ & $\begin{array}{l}\text { No obligation to assign } \\
\text { a person for additional } \\
\text { support }\end{array}$ & \multicolumn{3}{|c|}{$\begin{array}{l}\text { Obligation to assign a person } \\
\text { for additional support }\end{array}$} \\
\hline Country & $\begin{array}{l}\text { Germany, Belgium (Flanders), } \\
\text { The Netherlands, Greece }\end{array}$ & \multicolumn{3}{|l|}{ Sweden } \\
\hline
\end{tabular}

${ }^{a}$ Berlin and Brandenburg are the only two federal states (Bundesländer) in which pupils are tracked after 6th grade, i.e. at the age of 12

differentiation is often made between the obligation and the right to education. Having the right to education sounds perfect, but it does not necessarily imply state action to make it happen, unless families or pupils claim that right. And even then, the state may impose barriers, and there is no guarantee for the quality of the education that is offered. By contrast, the obligation to go to school also obliges the educational authorities to take action for making particular children or groups of children go to school. And: in the absence of obligatory school attendance, schools also have the right to reject refugee pupils (Crul, 2017, p. 5).

This represents a considerable barrier for the access to and equity in education of refugee children. Access to education is particularly compromised in immigration detention facilities: In nine out of 14 EU Member States covered by a survey of the Fundamental Rights Agency (FRA) children in detention centres have no access to any kind of formal education - if at all, it is provided by volunteers or NGOs (Fundamental Rights Agency, 2017, pp. 6-8). Language courses are often offered, and they are in some cases obligatory for those refugee children not attending school, but in most of the cases, this does not come even close to the intensity and duration of regular schooling (Crul, Keskiner, Schneider, Lelie, \& Ghaeminia, 2017, p. 6).

Another problematic and frequently overlooked aspect are the age limits (a) for the transition from primary to secondary education, and (b), even more so, for the end of 
compulsory education when strictly applied to youth that has probably missed years of education due to war or flight from conflict. Primary education is always general education and the fundament for all forms of education afterwards. Many educational systems apply tracking procedures in secondary education, 'sorting' children into tracks that may offer quite different educational possibilities in the future. Latecomers have a much higher chance of being streamed into the lower or lowest qualifying tracks in secondary education, frequently disregarding their actual capacities. This places these students not only at a disadvantage: 'detours' in educational trajectories contribute to the risk of early school leaving. Hence, latecomers are the most disadvantaged and an 'at risk' group in the tracking system.

A strict application of the age limit for compulsory education, most commonly around age 16, frequently results in truncated educational careers, especially among unaccompanied minors (UM) who fled from their countries before completing their first degree and arriving in EU countries that might not feel the obligation to provide them the possibility to complete a degree because of their age. By far the largest share of UM in Europe is 16 and older, and they are mostly streamed into different types of vocational training. Refugees older than 18 have even more limited access, if not no chances at all to still enter the educational system, although they might be needing only a short period for obtaining at least a secondary education degree (see Tudjman, Van den Heerik, Le Pichon, \& Baauw, 2016 for the example of the Netherlands). Apparently, this practice does not take into account the existing findings about second or third chances, including for those beyond the age of compulsory education, that significantly lower the risk of precarious and 'fragmented' labour market careers.

Other challenges for refugees' access to education include the frequently rural location of reception centres and the resulting limited access to appropriate educational institutional structures. Another inhibiting factor are the frequent moves in the process of being allocated to different reception centres during the asylum procedure (Koehler et al., 2018; Ravn, Nouwen, Clycq, \& Timmerman, 2018).

\section{Informed choices and connections with prior education}

In many European countries, education systems have rather complex structures and rules and provide for different trajectories and opportunities. Even for the second generation - i.e. the children of labour migrants - whose parents did not attend the education system of the country of residence, it has been difficult to understand all rules and procedures. In order for newly arrived migrant children and their families to be fully aware of the educational opportunities and possibilities and decide for the most appropriate options, comprehensive information and counselling offers are necessary. In most countries, reception centres and NGOs provide corresponding information; some cities have installed specific information centres, and some schools manage to provide targeted and individual guidance for refugees. In Belgium, for example, some schools organise 'network days' within reception education; these events aim to connect students, parents, principals, teachers and follow-up coaches. Overall, however, young refugees and their families feel insufficiently informed about the education systems, this is especially true for the stages of transition from reception to mainstream education and between different school types (Koehler et al., 2018). 
The diversity of education and schooling that refugee children have had prior to their arrival in Europe is a factor that clearly sets them apart from the second generation or immigrants who arrive in Europe at an early age. Some children and young people have had hardly any exposure to school in their countries of origin or missed out years of schooling because of war situations, while others come with degrees and participated in formal education without interruption (Koehler et al., 2018). EU countries have developed different methods for the assessment of prior education. Good practices do exist in Finland and Sweden: In Finland, an individual curriculum is to be designed within the first year in cooperation between the teacher, the pupil and the family for each student tailored to his/ her needs and based on their previous schooling, age and other factors affecting their school work (Dervin et al., 2017, pp. 5, 15). In Sweden, within 2 months of the arrival of a pupil at school, his/her previous schooling and level of knowledge and skills in literacy and mathematics are mapped. On this basis, the school decides on the grade to place the pupil in and on the additional support that will be provided; the school allocates teaching time for school subjects and makes mapping materials available in order to assess the pupil's prior knowledge. The Swedish model combines early insertion into regular education, i.e. a mainstream class where refugees will attend lessons according to their prior educational level, with the additional support that the pupils need to follow mainstream schooling (Ministry of Education and Research Sweden, 2016).

\section{Transitions from reception to mainstream education}

Administrative procedures and legal restrictions represent barriers for migrants' inclusion into education when access to schooling is dependent on their legal status or the stage in the asylum process (Koehler et al., 2018). Some countries (e.g. Italy) have made efforts to mitigate such barriers by allowing young refugees to obtain a school-leaving certificate, even if they reach the maximum age for the specific course before completing it (Grigt, 2017, p. 14).

The Fundamental Rights Agency found that in all surveyed EU countries, refugee pupils at mainstream schools have access to the same services as national pupils. However, following the principle of equity, it is necessary to provide additional support to refugee pupils, and this is especially important with regard to the particularities of their situation, such as e.g. trauma, loss of relatives, other psychosocial issues, and times without schooling. In most countries, measures have been introduced to meet refugee pupils' needs in schools through financial, educational or material support (Fundamental Rights Agency, 2017, p. 11). However, such support is not sufficiently provided in most cases, especially in countries where it is not obligatory to assign a support person to each school.

There are two main obstacles: lack of extra funds for this additional support and lack of well-trained personnel to deal with the specific needs and conditions of refugee children and UM in particular. In some countries (e.g. Sweden) it is obligatory to assign a particular support person for pupils who have attended a transition class, who supports the pupils individually or in groups, once they enter mainstream schools. In countries where there is no obligation to assign a support person - this applies to Germany, Belgium (Flanders), and the Netherlands - the type and quality of support varies. In some cases, a teacher or a school mentor takes up this role, but in most cases the support person is not specifically trained for the needs of refugee students and has to deal 
with lack of time. This often results in a situation where the needs of refugee students cannot appropriately be met and intervention support cannot be adequately provided (Crul et al., 2016, p. 13; Koehler et al., 2018). In Italy, for example, schools try to provide as much support to refugee and UM pupils as possible, but there is a lack of staff trained for teaching in multicultural classrooms and for responding to psychological needs, as well as a lack of linguistic and cultural mediation, also in order to communicate with parents (Grigt, 2017, pp. 26-27). In four of the countries surveyed by FRA - France, Slovakia, the Netherlands, and Sweden - there is some sort of support for traumatised children. However, this support often does not specifically target refugee children and might therefore be inadequate for their needs (Fundamental Rights Agency, 2017, pp. 11-12).

As has been identified above for the second generation, segregation remains a relevant obstacle to the integration into mainstream education for refugees in general. Empirical evidence indicates that segregation inhibits equal opportunities and has negative effects on the school performances of native and immigrant students and can lead to increased negative personal and social effects such as xenophobia, social exclusion, radicalisation and violence. Segregation is a result of different factors, for instance housing patterns and school selection. Some of these factors apply to migrants and refugees: middle-class parents tend to prefer schools with low shares of immigrants. Hence, their school choices reinforce segregation patterns. Measurements of the Duncan index - an index for the segregation of immigrants and natives in specific schools - indicate relatively high levels of segregation $(0,52-0,71)$ in ten EU countries ${ }^{16}$ (De Paola \& Brunello, 2017, p. 1 f.). However, other factors of segregation apply particularly to refugees: Housing arrangements for refugees and in some cases their residential segregation, with the attendant effects on education as well as segregation through separate educational arrangements seem to represent a challenge in many EU countries. In Italy, for example, refugee students are overly represented in courses at so-called Centri Provinciale di Istruzione per Adulti (CPIA). While they were initially developed for adult learners (native and migrants), they have over time turned into institutions that are regularly attended by refugees, especially UM students of age 16 and older. This limits their contacts to native-born peers considerably, which is why concerns of 'ghettoisation' have been expressed by several stakeholders (Grigt, 2017, pp. 24-25).

Another problem is that still too many teachers lack the training, competences and experience with issues of migration and diversity, to work with refugee students and their particular needs, to teach the national language as a second language, to provide psychosocial guidance, and to enable connections with the prior education of students. Teachers should be able to meet the diverse needs of all students and foster tolerance, respect for diversity and civic responsibility. Most European countries had previously not comprehensively managed to adapt teaching methods and quality to the needs of diversifying classrooms. These challenges intensified with the arrival of large numbers of refugee students (Koehler et al., 2018). The OECD (2014) finds that in many countries working with multicultural and multilingual students is among the areas that teachers feel the least prepared for.

This is why a number of EU countries have defined policy goals that target the improved preparation of teacher students for meeting the needs of diverse student populations (Public Policy Management Institute, 2017, p. 37). These policy goals are 
informed by different conceptualisations with regard to the operationalisation of diversity (e.g. linguistic or multicultural aspects, ethnic or national minorities) and the general view on diversity: The 'deficit view' considers diversity as a challenge to be taken up, while the 'potentials view' sees it as a benefit and educational opportunity (Public Policy Management Institute, 2017, p. 30). Countries increasingly adopt the 'potentials view' in recognising the benefits of cultural, linguistic, religious and social diversity for schools. Nevertheless, in many countries the 'deficit view' still prevails. At the same time, Initial Teacher Education (ITE)-systems in several EU countries have adopted more inclusive approaches in order to adjust to the needs of classroom diversity (Public Policy Management Institute, 2017, pp. 102-104).

\section{Trajectories after compulsory education}

Studies on migrant children have dedicated much attention to analysing the factors that promote their successful transition into higher and vocational education in order to close the representational gap between them and non-migrants in qualified vocational training and higher education. As mentioned above, the promoting factors include late or no tracking, providing second or third chances and longer educational careers. While these factors do also facilitate success for refugees, there are additional factors determining their successful trajectories in vocational or higher education.

Even though the Article 28 (1) (c) of the Convention of the Rights of the Child provides that Member States are to "make higher education accessible to all on the basis of capacity by every appropriate means" (OHCHR, 2016), the accessibility of higher education is severely restricted for refugee youth and even for newly arrived migrant children in general. The key obstacles to their access to tertiary education are legal status issues, the complicated procedures for recognising diplomas from asylum seekers' countries of origin and the language requirements for university admission (Fundamental Rights Agency, 2017, p. 14).

Challenges for refugees in accessing higher education are also due to the fact that policies for the professional development of refugees favour rather short-term vocational pathways on the EU level ${ }^{17}$ and - in Germany and the Netherlands - through national legislations, with a strong focus on support mechanisms for the transition and immersion phase. In combination with the effects of the early tracking system this leads to the majority of refugees entering the vocational sector after compulsory education. In the Netherlands and Germany, high language requirements and lack of information represent the main barriers for access to university (Crul, 2017; Koehler \& Schneider, 2018). However, some European universities circumvented strict regulations and preconditions, opened up their courses to refugees and invented preparatory programmes or 'bridging classes', in some cases in cooperation with the municipalities (Eurocities, 2017, p. 13; Grigt, 2017, p. 15).

By contrast, Swedish policies aim to give refugee students the same educational opportunities as native students which leads to many more efforts for making it possible for them to also reach higher education (Crul, 2017). Sweden provides unlimited access to university education; nevertheless there are also different measures to facilitate entry into the vocational sector. In Finland, the Ministry of Education and Culture has started a project in 2016 to strengthen the role of Finnish higher education institutions in integrating refugees. Refugees receive information about higher education careers 
and the recognition of previous degrees or years in higher education is fostered (Fundamental Rights Agency, 2017, p. 15). Italy was the first EU country that adopted the 'University for Refugees'. The initiative aims at creating educational corridors for higher education students and researchers who come as refugees. Scholarships were also provided by the Italian government and national organisations to facilitate the access for those students who were granted protection (Grigt, 2017, p. 15).

The Council of Europe (2017) further stresses the need for competences in the host country's language for any occupational field and any level of qualification. In this regard, it underlines the challenges of different needs for language training. General language training and competences can be sufficient for bringing low-skilled non-native speakers into work, the highly skilled need targeted and specific training which also applies to those with particular work-related communication needs.

\section{Lessons learned or mistakes repeated?}

As stated above, obviously, countries would not use the large influx of refugee and other newly arrived migrant children as an opportunity to undertake major changes to their respective educational systems in their basic aspects. Above mentioned systemic issues, such as the logic and timing of tracking, the age-bracket for compulsory education, or the role of formal achievements (grades, diplomas etc.) for the access to specific educational pathways were thus also unlikely to change - even though they might continue to have inhibiting effects. At the same time, some of the introduced ad-hoc measures in reaction to the immediate needs following the arrival of refugee children have a potential to produce also more general changes. These potential changes relate to how (different types of) schools deal with the steadily increasing linguistic diversity also in mainstream classes and the continuous need of incorporating newly arriving non-native speakers. Second-language teaching as a regular provision also at higher-level educational institutions, enhancing intercultural and multilingual competences in the teaching staff, and special bridging programmes in vocational education, for example, represent structural elements with high chances for becoming "normalised" features in at least some of the observed systems.

However, as shown above, there are also points that continue to be questioned and which, from our point of view, are interesting to see in international comparison. This is especially salient for the question of whether and for how long newly arrived immigrant or refugee children should be taught in separated welcome or reception classes to acquire certain levels of the host country language before being incorporated into mainstream or regular classes. German or Dutch teaching staff will mostly find it difficult to imagine the immediate immersion of young people without previous knowledge of the host language, while their colleagues in Sweden or the UK will have similar difficulties accepting the separation for as long as one or even 2 years. As shown in "Studies on previous second generations: what made a difference?" section, the experiences with separate classes in Germany in the 1980s and 1990s did have significant negative effects on the affected children's school and work careers. Separation also "invites" for discussions about required or wished for minimum levels of second-language skills before the transition and thus about the potential prolongation of the separation, if these are not yet attained. 
In the following, aiming at the current refugee youth in Europe, we summarise the major lessons to be learned from the previous experience of immigrant children in the different educational systems:

\section{$\checkmark$ Immersion is better than separation:}

Even though it seems an obvious thought that newly arriving immigrant or refugee children should first learn the basics of the host country's main vernacular before they can be incorporated into regular classes, this should be limited to a minimum period of time - depending on the age and grade. It is possible to integrate these children from the very start, and once there is a basic knowledge of the host language, the social environment of native-speaking peers will be an important element for speeding-up the learning process. But, immersion requires informed concepts, accompaniment and sufficient personnel to do so.

\section{$\checkmark$ Many refugee children will not go back:}

Every period of time not invested in children's education is wasted time with implications for even higher costs and efforts at later stages. Even though family deportations are happening and there might be a remote chance for peace in Syria, previous experiences teach us that many children and families will stay for good in the end. Thus, the element of costs and efforts is not 'only' relevant for the children themselves but also for the countries they came to.

\section{$\checkmark$ The phenomenon is most probably not temporal:}

In times of large-scale labour migration, it was presumed for far too long that the presence of immigrant children in schools would be transitory. Hence it was considered not worth to do much effort for adapting the system. Today, even though the scale of the refugee movement and the number of children to be integrated after 2015 was indeed exceptional in several destination countries, there will most likely be a constant influx of children of very diverse backgrounds and legal statuses also in the years to come, and for this influx adequate institutional responses are needed (in fact, today most pupils in German welcome classes are not refugees, but EU citizens). The challenge is to advance from the ad-hoc-measures taken in reaction to the immediate emergencies to more permanent structures and concepts that presume high levels of heterogeneity in classrooms as the most likely normality of schools also in the future.

\section{$\checkmark$ Education does not end at age 16 or 18 :}

'Late bloomers', i.e. students who only towards or after the end of compulsory education discover their ambitions and possibilities, tend to be more frequent among immigrant children than their native-born peers because of the generally more difficult starting positions and because of school discourses that tend to not assign them the same potential as their peers of native-born parentage. A lesson learned also from the Dutch case should be that there may be good reasons for educational careers gaining 
momentum only at later stages. And step-by-step careers into higher education can also be a valid alternative to straight pathways via academic tracks. While the age limits for compulsory education are frequently not applied too strictly in ongoing educational trajectories, they can make quite a difference when newly arrived youth are placed into the existing system or - as is frequently the case with those above age 18 - denied access at all. Because of pressure from the economic sector, especially in the field of vocational education the age limits were recently applied less strictly than before which has opened up many opportunities also for young adult refugees to enter the labour market through apprenticeships.

\section{$\checkmark$ Foreigners' and asylum legislation should not overrule perspectives of education and work:}

Throughout the past decades, foreigners' and asylum laws were regularly powerful enough to represent serious obstacles to educational perspectives and possibilities for work. Even performing well in school or having been offered an apprenticeship-position would rarely be enough to justify a more secure status on its own - against the interests of the affected young people as much as the employers and the schools. At the same time, all destination countries of refugees and immigrants in Europe are in need of young people - as labour force, as future high-skilled talents, and as tax payers - so offering a residency status on the basis of having found access to vocational training or to higher education can be considered a triple-win situation. To name one example: the German ' 3 plus 2-regulation' for young people on the apprenticeship-market offers them a secure status for the 3 years of vocational training plus 2 years for working in their acquired professions - independently from their previous status. This allows them and the companies to develop a reasonable perspective for career development and labour integration that is advantageous for all parties.

\section{$\checkmark$ Minors of age have a universal human right to education:}

Children's right to education is independent from their status, background and current country of residence. Refugee-receiving states tend to argue that this right can be fulfilled also in the country of origin and would thus not represent an obstacle to deportation. While it could be argued that some children are deported into countries whose educational systems are hardly able to effectively fulfil the right to education, it definitely represents a strong argument for an immediate access to education as soon as possible after the arrival which simply should and cannot wait, until their or their family's legal status and legal perspective have been checked by the authorities. It also means that refugee children cannot be offered a sort of 'second class-education', but that they receive the support needed to succeed, and that they are protected from discrimination. And it means that the access to schools must also be guaranteed for children without any legal status: schools must be exempted from any obligation to report them and their families to the immigration authorities.

While the institutional responses to the challenges posed by the new waves of refugee children (and immigrant children) are still in the making and are evolving in many 
aspects, there are some major lines that can already be identified. And they present a mixed picture: On the one hand, most systems aim at learning from previous lessons and avoiding mistakes made in the past. But on the other hand, the underlying idiosyncrasies seem more difficult to change, for example: to prefer separation over inclusion, to give more priority to national foreigners' law than to the universal children's right to education, and to rely more on ad-hoc responses designed for a limited period of time than on reflecting about the best possible way of dealing with a highly diverse student force also in the future and adapting the systems accordingly.

Finally, another lesson learned from especially the 'guest workers'-experience has been that expectations as regards the 'integration' of the first generation of adult immigrants should not be too high: Many low-educated immigrant workers will never learn the language of the host country well and will continue depending on a certain 'ethnic' infrastructure of shops and social relations for their daily needs - elements that are still quite frequently used in media and politics to state 'failed integration'. But, as research has shown, these immigrants nevertheless work and earn money, they pay taxes and rent, and - most importantly - they send their children to school and support them in becoming educated and building-up a professional perspective. For many immigrant families, it is the educational and professional success of the children that justifies and made worth the hardships, lean time and ambiguities of having left their home-country - so these parents are very aware of the importance of good quality education for their children and they thus provide them with all kinds of support (Crul, Keskiner, Schneider, \& Lelie, 2017; Lang, Pott, \& Schneider, 2016). And the same will be true for many refugee families, even when they do still not know what their future perspectives are.

From the perspective of the receiving countries, even for those children and youth whose perspectives to remain in the country do not seem very good, an investment in good education is never a waste of money and effort. There is obviously no harm done, if young people having to return or moving on to another country will do so with some newly acquired knowledge of Dutch, German or Swedish. ${ }^{18}$ But, in the end or in long-term perspectives, even many of those with apparently no chance for staying, in fact, will be staying for years or even for good. Disconnecting the access to good education from current estimations about their future thus avoids wasting precious time. And, from a human rights perspective, providing education as early and as complete as possible is not only in correspondence to international conventions, but also at least one important step for 'repairing' the effects of growing up in situations of war or extreme poverty.

\section{Endnotes}

${ }^{1}$ This may need some further explanations: in general, sociological definitions of 'second generation' refer to the native-born children of immigrants; however, frequently also small children before school age, but who were born abroad, are included (Crul \& Vermeulen, 2003; Schneider, 2016). Small children coming with their refugee parents are regularly not seen as $2^{\text {nd }}$ generation, and this is even true for those children who are actually born after the arrival of their refugee parents in the new country. However, after a certain period of time, children from immigrant families and refugee children are likely not be distinguished anymore by mainly referring to the legal status of their parents upon arrival. Instead, they will 'become' - certainly from the perspective of educational sociology - second generation. 
2"Immigrant Second Generation in Metropolitan New York"; see Kasinitz, Mollenkopf, and Waters (2004); Kasinitz, Mollenkopf, Waters, and Holdaway (2008) for details and main results.

3"Immigration and Intergenerational Mobility in Metropolitan Los Angeles"; see http://www.russellsage.org/research/Immigration/IIMMLA for details and publications.

4"Children of Immigrants Longitudinal Study"; see Portes and Rumbaut (2001, 2012) for details and main results. Recently, a team around Alejandro Portes and the Spanish migration researcher Rosa Aparicio applied the same research design to Madrid and Barcelona, the so-called ILSEG-Survey (see https://cmd.princeton.edu/publications/ data-archive/ilseg).

" "The Integration of the European Second Generation"; see Crul, Schneider, and Lelie (2012) for details and main results. Because TIES took up a similar questionnaire design as the US-surveys, some attempts were made to compare the European data also in transatlantic perspective (see Crul \& Mollenkopf, 2012).

${ }^{6}$ The most recently published comparative European research is the CILS4EU-project on adolescents in Germany, Sweden, the UK, and the Netherlands that - despite not being formally connected - follows the longitudinal design of the CILS-Survey mentioned above. Its focus for the first of three international waves is on adolescents in secondary education, but, as in TIES, education is just one aspect studied. The results in this field have just begun to be published; they especially seem to confirm the negative effects of school segregation (see below) on the structural integration of immigrant children (Kruse \& Kalter, 2018).

${ }^{7}$ Specifically, the TIES survey targeted the second generation of Turkish origin in seven of the eight countries (except Spain), of Moroccan origin in Belgium, the Netherlands and Spain, and of former Yugoslavian background in Austria, Germany and Switzerland. Additionally, in all countries also a group of age peers of non-immigrant descent was interviewed.

${ }^{8}$ Early school leaving (ESL) is defined here as having maximally obtained a middle diploma at the end of compulsory education that was not followed by any other completed step, neither in general nor in vocational education (e.g. having finished an apprenticeship). In order to restrict the analysis on context or system effects, the comparison is restricted to respondents of the Turkish second generation from low-educated families, i.e. those whose parents did not go to school for more than just a couple of years (Crul et al., 2012).

${ }^{9}$ See Crul et al. (2012) for these numbers and more in-depth analyses.

${ }^{10}$ The three tracks are Gymnasium (direct academic route into higher education), Realschule (preparing for more intellectually demanding vocations, such as commerce or banking) and Hauptschule (for unskilled workers and most crafts). Even comprehensive schools (Gesamtschulen) generally maintain the logic of the three tracks within their course systems. The main important difference is that there is more flexibility and differentiation: up to a certain grade, students can be at different levels in different subjects.

${ }^{11}$ See Lang et al. (2016) for detailed accounts from educationally and socially upwardly mobile individuals from workers families from Turkey between the late 1960s and the early 2000s in Germany.

${ }^{12}$ In fact, navigating the resulting complexity of the system can be considered a major challenge for newcomer families in the Netherlands (Crul \& Schneider, 2010). 
${ }^{13}$ See especially Crul and Schneider (2012); Crul et al. (2012).

${ }^{14}$ One of the ongoing research projects that will yield relevant outcomes in the near future is the longitudinal study 'Towards an Inclusive Education for Refugees: A Comparative Longitudinal Study' on Arab-speaking refugee children in Lebanon, Turkey, Germany and Australia by the Lebanese Study Center at the American-Lebanese University in Beirut that only in 2018 has started collecting the data for the first wave.

${ }^{15}$ Covering Belgium (Flanders), Bulgaria, Germany, Greece, the Netherlands, Sweden and the UK (primarily England) (see Kakos \& Sharma-Brymer, 2018; Koehler \& Schneider, 2018; Ravn et al., 2018; Tudjman et al., 2016).

${ }^{16}$ These are Hungary, Latvia, Great Britain, the Czech Republic, the Netherlands, France, Belgium, Denmark, Portugal, and Finland.

${ }^{17}$ The EU 'Action Plan on the integration of third country nationals' encourages Member States to mainly pursue fast integration into the labour market of newly arrived migrants, e.g. through combined language and on-the-job training, to remove obstacles for effective access to vocational training for refugees (also by assessing, validating and/or recognising skills and qualifications of third country nationals as soon as possible), and to encourage entrepreneurship (European Commission, 2016, pp. 10-11).

${ }^{18}$ This argument could even been taken further by connecting it to development policies. Many immigrants and refugees come from countries in development, and it is a well-established fact that 'skills transfer' and remittances tend to be more effective tools for development than 'regular' development aid projects.

\section{Abbreviations}

NGOs: Non-governmental organisations

Acknowledgements

No.

Funding

No funding was received.

Availability of data and materials

Not applicable.

Authors' contributions

Both authors have contributed to all sections of the article. Main responsibility for section 3 was with CK, for section 2 with JS. Responsibility for sections 1 and 4 was evenly shared between both authors. Both authors read and approved the final manuscript.

Authors' information

None.

Competing interests

The authors declare that they have no competing interests.

Publisher's Note

Springer Nature remains neutral with regard to jurisdictional claims in published maps and institutional affiliations.

Author details

${ }^{1}$ Farafina Institute, Bamberg, Germany. ${ }^{2}$ Institute for Migration Research and Intercultural Studies (IMIS), University of Osnabrück, Osnabrück, Germany.

Received: 4 March 2018 Accepted: 5 March 2019

Published online: 22 July 2019

References

Bonin, H. (2017). 'Education of migrants: A social investment', European expert network on economics of education (EENEE policy brief 3/2017). Retrieved from 24 May from http://www.eenee.de/eeneeHome/EENEE/Policy-Briefs.html. 
Council of Europe. (2017). 'Languages for work'. Retrieved on 27 May 2017 from http://www.coe.int/en/web/langmigrants/languages-for-work.

Crul, M. (2013). Snakes and ladders in educational systems. Access to higher education for second generation Turks in Europe. Journal of Ethnic and Migration Studies, 39(9), 1383-1401.

Crul, M. (2017). Refugee children in education in Europe. How to prevent a lost generation?' ( SIRIUS network policy brief series, issue no. 7). Retrieved from http://www.sirius-migrationeducation.org/wp-content/uploads/2018/10/Refugeechildren-in-education-in-Europe.-How-to-prevent-a-lost-generation.pdf.

Crul, M., Keskiner, E., Schneider, J., \& Lelie, F. (Eds.) (2017). The multiplier effect. How the accumulation of cultural and social capital explains steep upward mobility of children of low educated immigrants [Special Issue]. Ethnic and Racial Studies, 40(2), 321-338.

Crul, M. R. J., Keskiner, E., Schneider, J., Lelie, F., \& Ghaeminia, S. (2017). No lost generation? Education for refugee children: a comparison between Sweden, Germany, The Netherlands and Turkey. In R. Bauböck, \& M. Tripkovic (Eds.), The Integration of Migrants and Refugees: An EUI Forum On Migration, Citizenship And Demography, (pp. 62-80). [1] EUI. https://doi.org/10. 2870/30835.

Crul, M., Lelie, F., Biner, Ö., Bunar, N., Keskiner, E., Kokkali, l., ... Shuayb, M. (2019). How the different policies and school systems affect the inclusion of Syrian refugee children in Sweden, Germany, Greece, Lebanon and Turkey. Comparative Migration Studies, 7. https://doi.org/10.1186/s40878-018-0110-6.

Crul, M., Lelie, F., Keskiner, E., Schneider, J., \& Biner, Ö. (2019). Lost in transit. Education for refugee children in Sweden, Germany, and Turkey. In M. Suárez-Orozco (Ed.), Humanitarianism and mass migration: Confronting the world crisis, (pp. 268-290). Oakland: University of California Press.

Crul, M., \& Mollenkopf, J. (Eds.) (2012). The changing face of world cities: The second generation in Western Europe and the United States. New York: Russell Sage Foundation.

Crul, M., \& Schneider, J. (2009). Children of Turkish Immigrants in Germany and the Netherlands: The Impact of Differences in Vocational and Academic Tracking Systems. Teachers College Record, 111(6), 1508-1527.

Crul, M., \& Schneider, J. (2010). Comparative integration context theory: Participation and belonging in new diverse European cities. Ethnic and Racial Studies, 33, 1249-1268.

Crul, M., \& Schneider, J. (2012). Conclusions and implications: The integration context matters. In M. Crul, J. Schneider, \& F. Lelie (Eds.), The European second generation compared: Does the integration context matter? (pp. 375-403). Amsterdam: Amsterdam University Press.

Crul, M., Schneider, J., \& Lelie, F. (Eds.) (2012). The European second generation compared. Does the integration context matter? Amsterdam: University Press.

Crul, M., Schnell, P., Herzog-Punzenberger, B., Wilmes, M., Slootman, M., \& Aparicio-Gómez, R. (2012). School careers of second-generation youth in Europe: Which education systems provide the best chances for success? In M. Crul, J. Schneider, \& F. Lelie (Eds.), The European second generation compared: Does the integration context matter? (pp. 101-164). Amsterdam: Amsterdam University Press.

Crul, M., \& Vermeulen, H. (2003). The second generation in Europe. International Migration Review, 37, 965-986.

De Paola, M., \& Brunello, G. (2017). School segregation of immigrants and educational outcomes in Europe, European expert network on economics of education (EENEE Policy Brief 2/2017). Retrieved from http://www.eenee.de/ eeneeHome/EENEE/Policy-Briefs.html.

Dervin, F., Simpson, A., \& Matikainen, A. (2017). 'EDINA country report - Finland'. Retrieved from: https://edinaplatform.eu/content/ edina/2-research/1-country-reports/Country-Report-Finland.pdf.

Eurocities (2017). Cities' actions for the education of refugees and asylum seekers. Brussels. Retrieved from http://nws. eurocities.eu/MediaShell/media/Education\%20report_Final\%20Version.pdf.

European Commission (2016). Communication from the commission to the European parliament, the council, the European economic and social committee and the committee of the regions - action plan on the integration of third country nationals. Brussels. Retrieved from https://ec.europa.eu/home-affairs/sites/homeaffairs/files/what-we-do/ policies/european-agenda-migration/proposal-implementation-package/docs/20160607/communication_action_plan_ integration_third-country_nationals_en.pdf.

Fazel, M., Reed, R. V., Panter-Brick, C., \& Stein, A. (2012). Mental health of displaced and refugee children resettled in highincome countries: Risk and protective factors. The Lancet, 379(9812), 266-282.

Fundamental Rights Agency (2017). 'Current migration situation in the EU: Education'. Retrieved from https://fra. europa.eu/en/publication/2017/current-migration-situation-eu-education.

Grigt, S. (2017). The Journey of Hope: Education for Refugee and Unaccompanied Children in Italy. Retrieved from https://issuu.com/educationinternational/docs/grigt_journey_of_hope_2017.

Kakos, M., \& Sharma-Brymer, V. (2018). Multi-country partnership to enhance the education of refugee and asylum-seeking youth in Europe - Education of children from refugee and asylum-seeker background in England, UK. Leeds Becket University and SIRIUS - Policy Network on Migrant Education. Brussels.

Kasinitz, P., Mollenkopf, J., \& Waters, M. (2004). Becoming New Yorkers: Ethnographies of the new second generation. New York: Russell Sage Foundation.

Kasinitz, P., Mollenkopf, J., Waters, M., \& Holdaway, J. (2008). Inheriting the city. The children of immigrants come of age. New York: Russel Sage.

Koehler, C. (2017). Continuity of learning for newly arrived refugee children in Europe (NESET II ad hoc question No. 1/2017). Retrieved from http://nesetweb.eu/wp-content/uploads/2016/02/Refugee-children.pdf.

Koehler, C., Kakos, M., Sharma-Brymer, V., Schneider, J., Tudjman, T., Van den Heerik, A., . . Toumpoulidis, G. (2018). Multi-country partnership to enhance the education of refugee and asylum-seeking youth in Europe PERAE (Comparative Report). SIRIUS - Policy Network on Migrant Education, Brussels. Retrieved from https:// www.researchgate.net/publication/326113676_SIRIUS-Policy_Network_on_Migrant_Education_MULTICOUNTRY_ PARTNERSHIP_TO_ENHANCE_THE_EDUCATION_OF_REFUGEE_AND_ASYLUM-SEEKING_YOUTH_IN_ EUROPEPERAE_Comparative_Report.

Koehler, C., \& Schneider, J. (2018). Multi-country partnership to enhance the education of refugee and asylum-seeking youth in Europe. National report Germany, European forum for migration studies, Verikom and SIRIUS - Policy network on migrant education. 
Kruse, H., \& Kalter, F. (2018). Learning together or apart? Ethnic segregation in lower secondary schools. In F. Kalter, J. O. Jonsson, F. van Tubergen, \& A. Heath (Eds.), Growing up in diverse societies: The integration of children of immigrants in England, Germany, the Netherlands and Sweden. Oxford: Oxford University Press.

Lang, C., Pott, A., \& Schneider, J. (2016). Unwahrscheinlich erfolgreich. Sozialer Aufstieg in der Einwanderungsgesellschaft [Incredible successful. Social upward mobility in the immigration society]. IMIS-Beiträge Heft 49. Osnabrück: IMIS.

Ministry of Education and Research Sweden (2016). 'Sweden's presentation fiche session 1: Organisation of introductory classes.

OECD (2006). Where Immigrant Students Succeed - A Comparative Review of Performance and Engagement in PISA 2003. Paris: OECD Publishing Retrieved from http://www.oecd.org/education/school/programmeforinternationalstudentassessmentpisa/ whereimmigrantstudentssucceed-acomparativereviewofperformanceandengagementinpisa2003.htm.

OECD (2014). Education at a glance 2014: OECD indicators. OECD Publishing Retrieved from https://www.oecd.org/edu/Educationat-a-Glance-2014.pdf.

OECD (2015). Helping immigrant students to succeed at school - and beyond. Paris: OECD Retrieved from https://www.oecd.org/ education/Helping-immigrant-students-to-succeed-at-school-and-beyond.pdf.

OHCHR (2016). 'Convention on the rights of the child'. Retrieved from http://www.ohchr.org/Documents/Professionallnterest/ crc.pdf.

Portes, A., \& Rumbaut, R. (2001). Legacies: The story of the immigrant second generation. Berkeley; New York: University of California Press.

Portes, A., \& Rumbaut, R. (2012). Children of immigrants longitudinal study (CILS), 1991-2006. Ann Arbor: ICPSR.

Public Policy and Management Institute (2017). Preparing teachers for diversity: The role of initial teacher education. Brussels: European Commission. Retrieved from https://publications.europa.eu/en/publication-detail/-/publication/b347bf7d-1db111e7-aeb3-01aa75ed71a1/language-en.

Ravn, S., Nouwen, W., Clycq, N., \& Timmerman, C. (2018). Multi-country partnership to enhance the education of refugee and asylum-seeking youth in Europe -Refugee education in Flanders (Belgium). Centrum for Migration and Intercultural Studies and SIRIUS - Policy Network on Migrant Education.

Rydin, I., Eklund, M., Högdin, S., \& Sjörberg, U. (2012). Country report Sweden. In A. Nonchev, \& N. Tagarov (Eds.), Integrating refugee and asylum seeking children in the educational systems of the EU member states, p. 182. Sofia: CSD.

Schneider, J. (2016). First/second generation immigrants (NESET II ad hoc question no. 4/2016). Retrieved from http://nesetweb. eu/wp-content/uploads/2016/02/NESET2_AHQ4.pdf.

Tudjman, T., Van den Heerik, A., Le Pichon, E., \& Baauw, S. (2016). Multi-country partnership to enhance the education of refugee and asylum-seeking youth in Europe - Refugee education in the Netherlands. Risbo -Erasmus University Rotterdam.

\section{Submit your manuscript to a SpringerOpen ${ }^{\circ}$ journal and benefit from:}

- Convenient online submission

Rigorous peer review

- Open access: articles freely available online

- High visibility within the field

- Retaining the copyright to your article

Submit your next manuscript at $\boldsymbol{\nabla}$ springeropen.com 